\title{
The Synoptic Regulation of Dryline Intensity
}

\author{
DAVID M. SCHULTZ* \\ Cooperative Institute for Mesoscale Meteorological Studies, University of Oklahoma, and NOAA/National Severe Storms Laboratory, \\ Norman, Oklahoma \\ Christopher C. Weiss \\ Atmospheric Science Group, Department of Geosciences, Texas Tech University, Lubbock, Texas \\ Paul M. Hoffman \\ Massachusetts Institute of Technology, Cambridge, Massachusetts
}

(Manuscript received 11 July 2006, in final form 18 August 2006)

\begin{abstract}
To investigate the role of synoptic-scale processes in regulating the strength of the dryline, a dataset is constructed of all drylines occurring within the West Texas Mesonet (WTM) during April, May, and June of 2004 and 2005. In addition, dewpoint and wind data were collected from stations on the western (Morton; MORT) and eastern (Paducah; PADU) periphery of the WTM domain (230 km across), generally oriented east-west across the typical location of the dryline in west Texas. Drylines were characterized by two variables: the difference in dewpoint between MORT and PADU (hereafter, dryline intensity) and the difference in the eastward component of the wind between MORT and PADU (hereafter, dryline confluence). A high degree of correlation existed between the two variables, consistent with a strong role for dryline confluence in determining dryline intensity. Some cases departing from the strong correlation between these variables represent synoptically quiescent drylines whose strength is likely dominated by boundary layer mixing processes.

Composite synoptic analyses were constructed of the upper and lower quartiles of dryline intensity, termed STRONG and WEAK, respectively. STRONG drylines were associated with a short-wave trough in the upper-level westerlies approaching west Texas, an accompanying surface cyclone over eastern New Mexico, and southerly flow over the south-central United States. This synoptic environment was favorable for enhancing the dryline confluence responsible for strengthening the dryline. In contrast, WEAK drylines were associated with an upper-level long-wave ridge over Texas and New Mexico, broad surface cyclogenesis over the southwestern United States, and a weak lee trough-the dryline confluence favorable for dryline intensification was much weaker. A third composite termed NO BOUNDARY was composed of dates with no surface airstream boundary (e.g., front, dryline) in the WTM domain. The NO BOUNDARY composite featured an upper-level long-wave ridge west of Texas and no surface cyclone or lee trough. The results of this study demonstrate the important role that synoptic-scale processes (e.g., surface lee troughs, upper-level short-wave troughs) play in regulating the strength of the dryline. Once such a favorable synoptic pattern occurs, mesoscale and boundary layer processes can lead to further intensification of the dryline.
\end{abstract}

\section{Introduction}

The dryline is an airstream boundary (e.g., Cohen and Kreitzberg 1997; Cohen and Schultz 2005) separat-

\footnotetext{
* Current affiliation: Division of Atmospheric Sciences, Department of Physical Sciences, University of Helsinki, and Finnish Meteorological Institute, Helsinki, Finland.

Corresponding author address: Dr. David M. Schultz, NOAA/ National Severe Storms Laboratory/FRDD, Room 4360, 120 David L. Boren Blvd., Norman, OK 73072.

E-mail: david.schultz@noaa.gov
}

DOI: 10.1175/MWR3376.1

(C) 2007 American Meteorological Society ing moist air originating over the Gulf of Mexico from dry air originating over the southwestern United States and high plateau of Mexico (e.g., Fujita 1958; Beebe 1958; Rhea 1966; Schaefer 1974a, 1986). The dryline typically forms along the high plains in the spring months and is a frequent site of convection initiation. The details of the processes that control convection initiation along the dryline, however, remain elusive (e.g., Ziegler and Rasmussen 1998; Richter and Bosart 2002).

Previous literature has suggested that a strengthening dryline is favorable for convection initiation (e.g., Hane et al. 1993; Ziegler et al. 1997; Hane et al. 1997; Ziegler and Rasmussen 1998; Atkins et al. 1998). For example, 
during the 3 May 1999 tornado outbreak in Oklahoma and Kansas, Storm Prediction Center forecasters were focused on the dryline for indications of convection initiation (Table 1 in Roebber et al. 2002). The dryline did not strengthen, although tornadic supercells did form $50 \mathrm{~km}$ away from the dryline, indicating the difficulty in forecasting convection initiation near the dryline (Thompson and Edwards 2000). The failure of the dryline to intensify as anticipated on 3 May 1999 provides a dramatic example that convection initiation may not be related to the strength of the dryline, or to the dryline at all. The failure of this conceptual model begs the following two questions: What processes control the strength of the dryline? Is convection initiation related to the strength of the dryline? The present paper addresses the first question by examining the synopticscale influences on dryline intensity. A future paper will address the second question.

Finescale mobile surface observations (e.g., Ziegler and Hane 1993; Ziegler and Rasmussen 1998) and aircraft observations (e.g., Geerts et al. 2006) show that the width of the dryline can be as small as 500-1000 m and the moisture gradient can exceed a few grams per kilogram per kilometer. Previously identified processes affecting the strength of the dryline can be classified into three groups: mixing, frontogenesis, and synopticscale processes. For example, a horizontal gradient in vertical mixing is often credited with increasing the strength of the dryline (e.g., Schaefer 1974b, 1986; Sun and $\mathrm{Wu}$ 1992; Miller et al. 2001; Jones and Bannon 2002), as accumulated sensible surface heating through the course of a diurnal cycle mixes a progressively deeper, moist convective boundary layer in the downterrain direction with the dry free atmosphere above. Furthermore, mesoscale processes like frontogenetical circulations associated with virtual temperature contrasts across the dryline can produce ageostrophic circulations that lead to dryline intensification (e.g., Sun and Ogura 1979; Ziegler et al. 1995; Weiss and Bluestein 2002; Weiss et al. 2006) in the same manner as occurs with fronts (e.g., Hoskins and Bretherton 1972). In contrast, previous literature (e.g., McCarthy and Koch 1982; Schaefer 1986; Peckham and Wicker 2000 ) is relatively quiet on the topic of what synopticscale processes control the strength of the dryline.

The purpose of this paper is to examine the synopticscale processes that affect the strength of the dryline. In section 2, surface data from the West Texas Mesonet (WTM; Schroeder et al. 2005) are used to define days when drylines are present and provide measures of dryline strength. Section 3 discusses the relationship between several different measures of dryline strength.

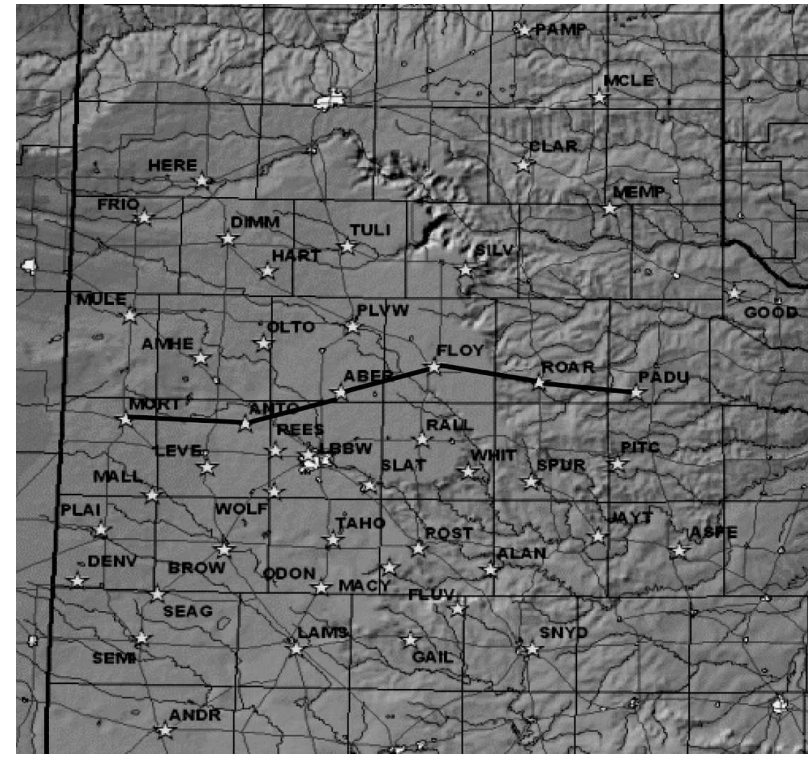

FIG. 1. Map of the West Texas Mesonet (as of November 2005). Thick solid lines connect stations identified in text.

In section 4, synoptic composites of days with strong versus weak drylines are constructed using the National Centers for Environmental Prediction-National Center for Atmospheric Research (NCEP-NCAR) reanalysis dataset (Kalnay et al. 1996) to understand the synopticscale processes acting to regulate dryline strength. Section 5 discusses these results in the context of other literature and current conceptual models of drylines. Finally, section 6 concludes this paper.

\section{Construction of the dryline dataset}

Cases were selected from all 182 spring (April, May, and June) days in 2004 and 2005. These months have been previously used by other investigators in their dryline studies because the dryline is best defined in spring (e.g., Rhea 1966; Schaefer 1974a; Peterson 1983; Hoch and Markowski 2005). Dryline cases were selected for those days that satisfied the following criteria from WTM data.

- The dewpoint gradient had an eastward (downterrain) component.

- The majority of the dewpoint gradient (determined from surrounding synoptic observations) resided within the WTM domain (Fig. 1).

- The dewpoint gradient was not attributed to a cold front or warm front.

- The dewpoint gradient was not influenced by convective outflow.

- The dewpoint difference between stations Morton 
(MORT) and Paducah (PADU) (a distance of 230 $\mathrm{km}$; see Fig. 1 for locations of these stations) increased between 0700 and 1800 local time (LT) (between 1200 and 2300 UTC for most cases).

- The region of maximum dewpoint gradient either slowed down its eastward progress or moved westward after $1800 \mathrm{LT}$, when the sensible heat flux and vertical mixing were inferred to be no longer potentially significant for dryline progression.

These criteria were chosen to select cases where the dewpoint difference between MORT and PADU increased because of diurnally driven sensible heating on a sloped terrain (e.g., Schaefer 1974b, 1986; Sun and Wu 1992; Miller et al. 2001; Jones and Bannon 2002). Any airstream boundaries that did not meet the last criterion were clearly fronts; no drylines were excluded from our dataset because of this last criterion. Furthermore, because we define a dryline by its gradient in moisture, no condition on surface wind convergence was included. This definition differs from that of Rhea (1966), who defined the dryline as "the first organized line of veering surface wind, even though, in a few cases, this wind-shift line preceded the strongest surface dew-point drop." In fact, seven cases in our dataset satisfying our criteria exhibited weak diffluence over the WTM domain; these were identified as drylines and included in our dataset.

The selection method described above yielded a total of 64 cases for the two seasons, 40 for 2004 and 24 for 2005. All dryline days were ranked according to four variables that were calculated. These four variables included the following:

- the difference in dewpoint temperature between MORT and PADU $\left(\Delta T_{d}\right.$; hereafter, dryline intensity);

- the maximum difference in dewpoint temperature between any two stations along the east-west line of stations MORT, Anton (ANTO), Abernathy (ABER), Floydada (FLOY), Roaring Springs (ROAR), and PADU $\left(\Delta T_{d, \max }\right)$;

- the difference in the $u$ component of the velocity between MORT and PADU ( $\Delta u$; hereafter dryline confluence); and

- the change between 0700 and 1800 LT in the difference in the dewpoint between MORT and PADU $\left[\Delta\left(\Delta T_{d}\right)\right]$.

Both $\Delta T_{d, \text { max }}$ and $\Delta\left(\Delta T_{d}\right)$ were strongly correlated to $\Delta T_{d}$ (Pearson correlation coefficients of $R=0.87$ and $R=0.82$, respectively). Thus, these two variables are not considered further. The relationship between

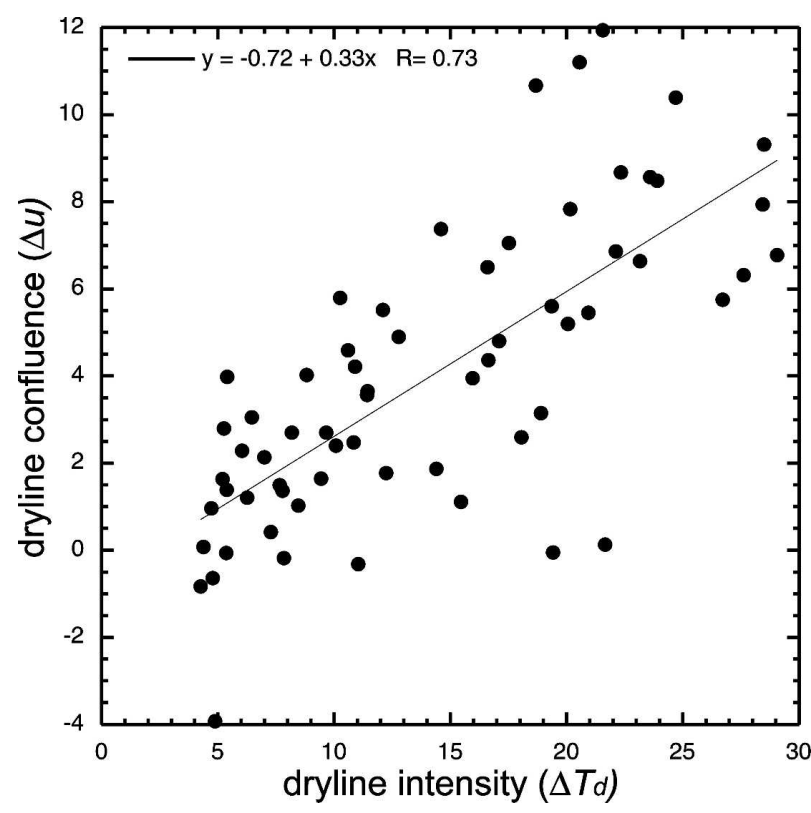

FIG. 2. Scatterplot of dryline intensity $\left(\Delta T_{d}\right)$ vs dryline confluence $(\Delta u)$ from 64 dryline days in 2004 and 2005 (see text for criteria). The gray line represents linear regression of data.

dryline intensity and dryline confluence is discussed in the next section.

\section{Relationship between dryline intensity and dryline confluence}

The relationship between dryline intensity $\left(\Delta T_{d}\right)$ and dryline confluence $(\Delta u)$ shows a linear relationship with Pearson correlation coefficient $R=0.73$ (Fig. 2). This graph suggests that the amount of confluence of air parcels across the dryline is playing an important role in dryline intensity. Despite the correlation, the spread about the line is still quite substantial, with occasional large departures from this linear relationship, particularly for some of the more intense drylines with small positive or weak negative values of dryline confluence. Many of these cases are synoptically quiescent drylines, where vertical-mixing processes dominate the synopticscale processes producing confluence, as opposed to the synoptically active drylines where synoptic-scale processes dominate vertical mixing. [This suggested classification scheme was formalized by Hane (2004) based on terminology introduced by Schaefer (1986).] Nevertheless, confluence may be occurring on a narrower spatial scale about the dryline than reported in the WTM observations. For example, the frontogenetical circulation about the dryline may produce confluence on scales smaller than the data from MORT and PADU can resolve. Nevertheless, the results from Fig. 
2 suggest that, for the criteria we used for dryline selection, a strong correlation exists between dryline confluence (as measured by the difference in the $u$ component of the wind over a distance of $230 \mathrm{~km}$ ) and dryline intensity.

\section{Composite results}

To examine the difference in the synoptic patterns for days with strong versus weak drylines, the top and bottom quartiles of $\Delta T_{d}$ and $\Delta u$ rankings at $1800 \mathrm{LT}$ were constructed. Days in the top quartile of $\Delta T_{d}$ were termed STRONG dryline days; days in the bottom quartile of $\Delta T_{d}$ were termed WEAK dryline days (Table 1). Because 64 days were in our dataset, each quartile consisted of 16 days. Composite fields constructed from the top and bottom quartiles of the $\Delta T_{d}$ and $\Delta u$ rankings were created at the National Oceanic and Atmospheric Administration-Cooperative Institute for Research in Environmental Sciences (NOAACIRES) Climate Diagnostics Center Web site (http:// www.cdc.noaa.gov) using the NCEP-NCAR reanalysis dataset (Kalnay et al. 1996) at 0000 UTC (1900 LT for most dates). Composite results for the top quartiles of $\Delta T_{d}$ and $\Delta u$ were similar, as were the results for the bottom quartiles (not shown); thus, we present just one set of composites for brevity, those based on $\Delta T_{d}$.

The difference in the synoptic patterns between STRONG and WEAK dryline days is quite substantial. STRONG dryline days possessed a composite $250-\mathrm{hPa}$ jet maximum of $25-30 \mathrm{~m} \mathrm{~s}^{-1}$ over the eastern Pacific Ocean (Fig. 3a), and a 500-hPa short-wave trough over the western United States was approaching west Texas (Fig. 3c). This upper-tropospheric forcing was associated with a composite surface cyclone with central pressure less than $1004 \mathrm{hPa}$ over eastern New Mexico and western Texas (Fig. 3e). Strong, moist geostrophic flow from the south is implied by the nearly north-south isobars extending from the Gulf of Mexico to Nebraska (Fig. 3e). Such a synoptic pattern is consistent with that discussed by Uccellini (1980) associated with low-level jets over the south-central United States (his type 1 events). A surface lee trough extends equatorward from the cyclone center in western Texas (Fig. 3e). Implied surface confluence associated with this lee trough is consistent with the large gradient of $u$ across the Texas panhandle (Fig. 4a) and the large values of $\Delta u$ for cases comprising the STRONG composite (e.g., Fig. 2). This strong confluence of the wind contributes to the strong gradients in dewpoint temperature (Fig. 4c) and 850-hPa relative humidity (Fig. 5c) across west Texas.

In contrast to the STRONG composite, WEAK dryline days possessed a $250-\mathrm{hPa}$ jet much farther pole-
TABLE 1. Cases in STRONG vs WEAK composites.

\begin{tabular}{cc}
\hline \hline STRONG & WEAK \\
\hline 17 May 2004 & 1 Apr 2004 \\
18 May 2004 & 14 Apr 2004 \\
2 Jun 2004 & 15 Apr 2004 \\
10 Jun 2004 & 26 Apr 2004 \\
11 Jun 2004 & 4 May 2004 \\
12 Jun 2004 & 8 May 2004 \\
13 Jun 2004 & 10 May 2004 \\
21 Jun 2004 & 16 May 2004 \\
20 Apr 2005 & 4 Jun 2004 \\
7 May 2005 & 20 Jun 2004 \\
11 May 2005 & 27 Jun 2004 \\
13 May 2005 & 2 Apr 2005 \\
17 May 2005 & 20 Jun 2005 \\
9 Jun 2005 & 22 Jun 2005 \\
12 Jun 2005 & 24 Jun 2005 \\
18 Jun 2005 & 28 Jun 2005 \\
\hline
\end{tabular}

ward over the north-central United States (Fig. 3b) and a $500-\mathrm{hPa}$ ridge over the south-central United States (Fig. 3d). At the surface, WEAK dryline days were associated with a broad low pressure area over the southwestern United States and northwestern Mexico (Fig. 3f) and a weak lee trough; the surface geostrophic southerly flow was about a third weaker than that of the STRONG composite (cf. Figs. 3e,f). Surface confluence in west Texas with this surface pressure pattern was much smaller (Fig. 4b), consistent with the small values of $\Delta u$ for cases comprising the WEAK composite (e.g., Fig. 2). The weak cross-dryline variation in the $u$ component of the wind resulted in a weak gradient in surface dewpoint temperature (Fig. 4d) and 850-hPa relative humidity (Fig. 5d) across west Texas.

These composites illustrate why there is a strong relationship between $\Delta T_{d}$ and $\Delta u$ in Fig. 2. The strong convergence and deformation associated with the surface cyclone creates an environment favorable for an airstream boundary (e.g., Cohen and Kreitzberg 1997), as shown by Eq. (8a) for the instantaneous contraction rate discussed in Cohen and Schultz (2005). More specifically, convergence and deformation are responsible for causing contraction in the wind field (Cohen and Schultz 2005), similar to that for frontogenesis acting on the horizontal temperature gradient. Thus, the largescale gradient in moisture across the south-central United States is intensified by the contraction associated with the surface cyclone. Similar processes along the Australian dryline have been examined using the Cohen and Schultz (2005) diagnostics by Arnup and Reeder (2007).

Other composite fields provide further insight into the synoptic-scale processes associated with the STRONG and WEAK composites. For example, the 


\section{STRONG WEAK}

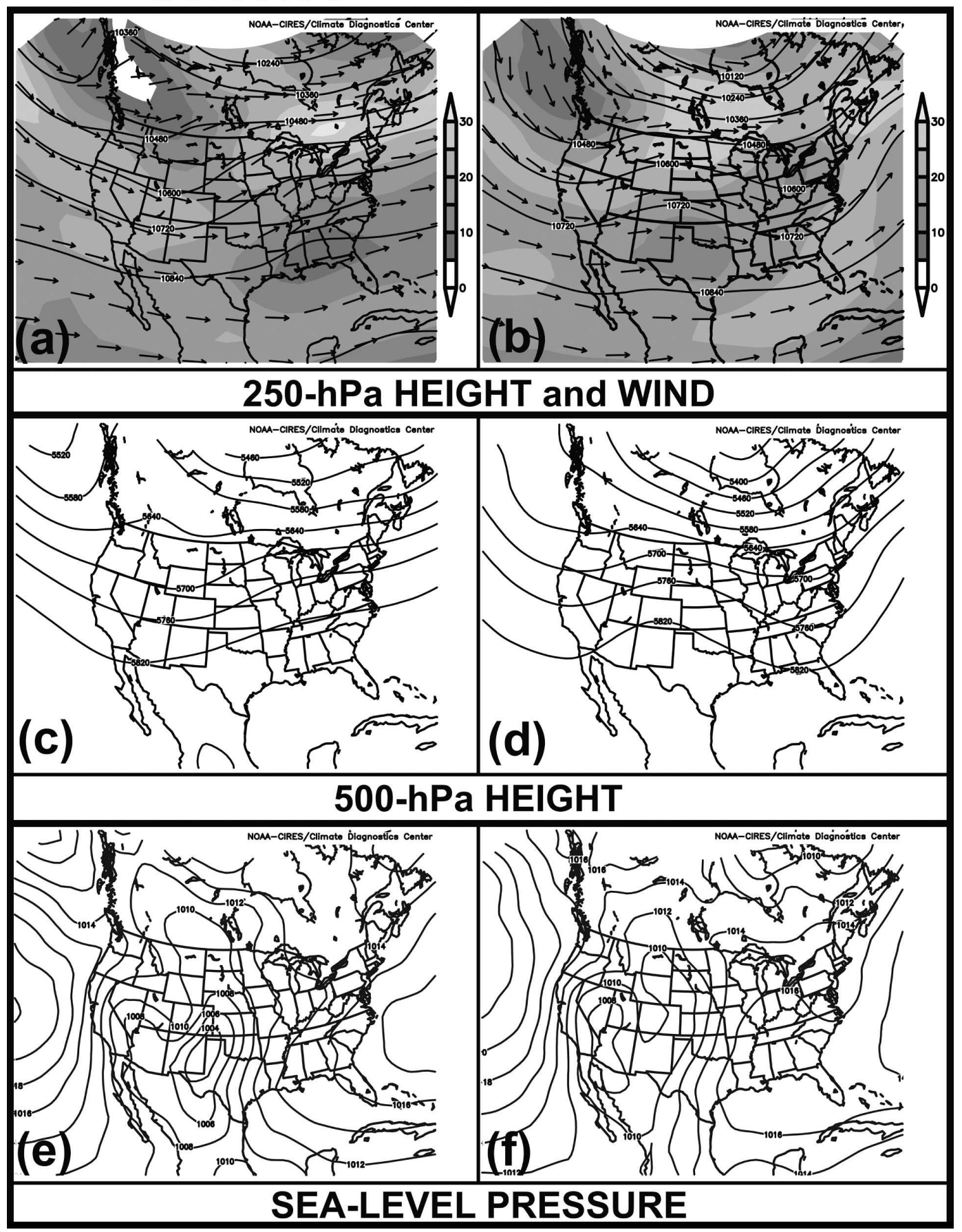

FIG. 3. (left) STRONG vs (right) WEAK dryline composites: (a) and (b) 250-hPa geopotential height (solid lines every $120 \mathrm{~m}$ ), wind speed ( $\mathrm{m} \mathrm{s}^{-1}$, shaded according to scale), and wind direction (vectors); (c) and (d) 500-hPa geopotential height (solid lines every $60 \mathrm{~m}$ ); (e) and (f) sea level pressure (solid lines every $2 \mathrm{hPa}$ ).

short-wave trough approaching west Texas in the STRONG composites was associated with a temperature gradient featuring colder air to the northwest of the dryline in New Mexico and Colorado both at 700-
$\mathrm{hPa}$ and at the surface (Figs. 5a,e). This 700-hPa temperature gradient is not associated with the dryline. In contrast, lower-tropospheric thermal gradients in the WEAK composites are weaker at the surface (Fig. 5f) 


\section{STRONG}

\section{WEAK}

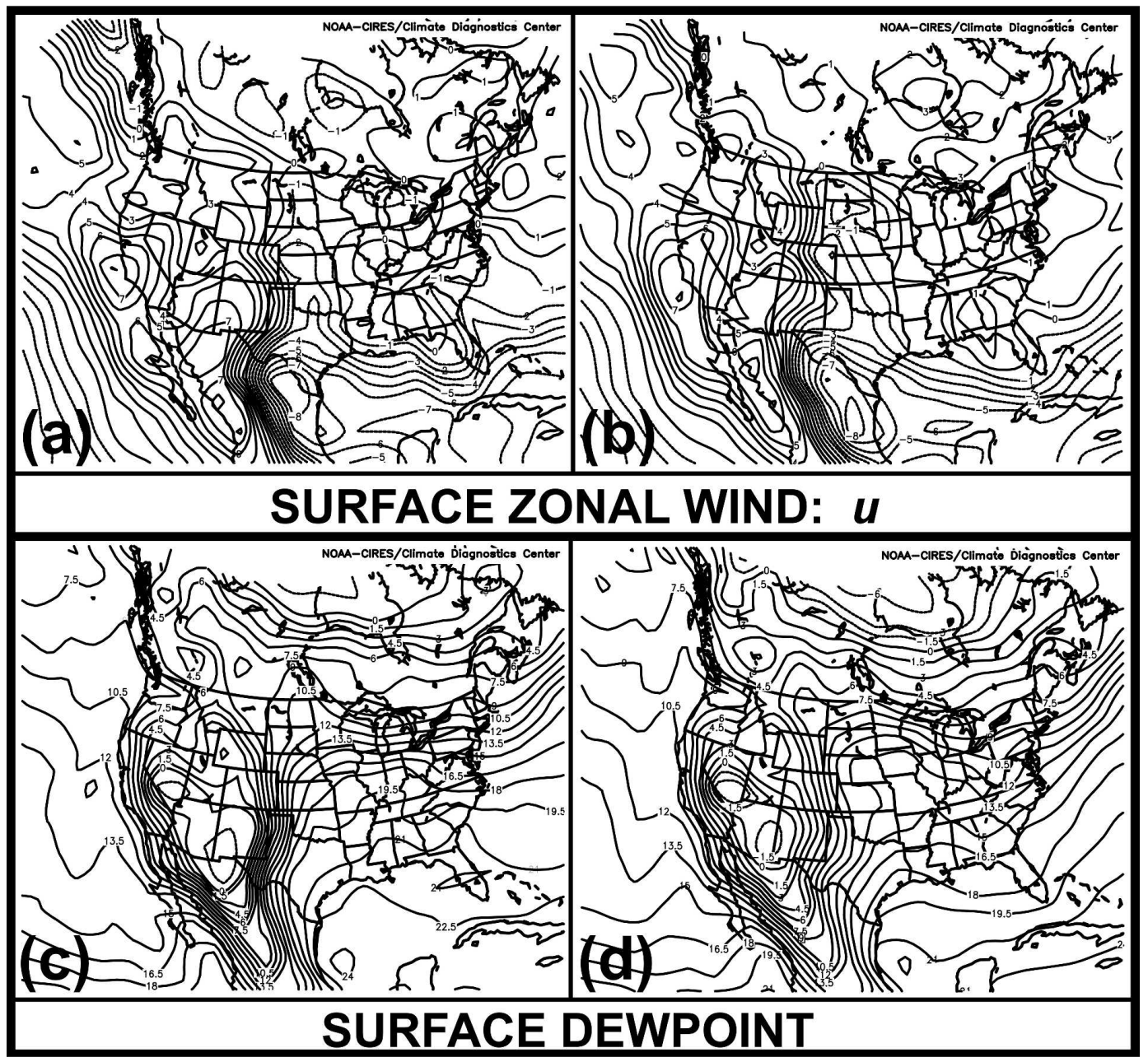

FIG. 4. (left) STRONG vs (right) WEAK dryline composites: (a) and (b) surface zonal wind [every $1 \mathrm{~m} \mathrm{~s}^{-1}$; positive and zero (negative) values solid (dashed)]; (c) and (d) surface dewpoint [every $1.5^{\circ} \mathrm{C}$; positive and zero (negative) values solid (dashed)].

and are found farther to the northwest away from west Texas (Fig. 5b). The 700-hPa temperature also serves as a good measure of the strength of the capping inversion on dryline days (e.g., Hane et al. 1997) because the vertical resolution of the NCEP-NCAR reanalysis data was insufficient to fully resolve the inversion. The composite temperature of $10.5^{\circ}-12^{\circ} \mathrm{C}$ over west Texas in the STRONG case contrasts with the 700-hPa temperature of $9^{\circ}-10.5^{\circ} \mathrm{C}$ over west Texas in the WEAK cases (cf. Figs. 5a,b), implying that stronger drylines tend to be associated with a more significant thermal inversion, which is responsible for precluding convection initiation in many cases. The strength of this capping inversion is connected to the eastward advection of air with high potential temperature from the mixed layer west of the dryline (e.g., Carlson et al. 1983), and secondary ageostrophic circulations often occur along its edge (e.g., Keyser and Carlson 1984). Stronger drylines are typically associated with more pronounced drylinenormal (westerly) flow to the west of the dryline (cf. Figs. 4a,b), assisting in the increasing confluence typically observed (e.g., Fig. 2). Therefore, the eastward advection of the mixed layer should indeed be more significant in the stronger dryline cases.

Finally, we examine two parameters useful for diagnosing the potential for convective storms. The lapse rate between 700 and $500 \mathrm{hPa}$ provides a measure of the location of the elevated mixed-layer air originating over the elevated terrain of the southwestern United States and northern Mexico. In addition, the subsidence behind the $500-\mathrm{hPa}$ trough and associated surface cyclone from air with previous history of descent (the dry 
STRONG

WEAK

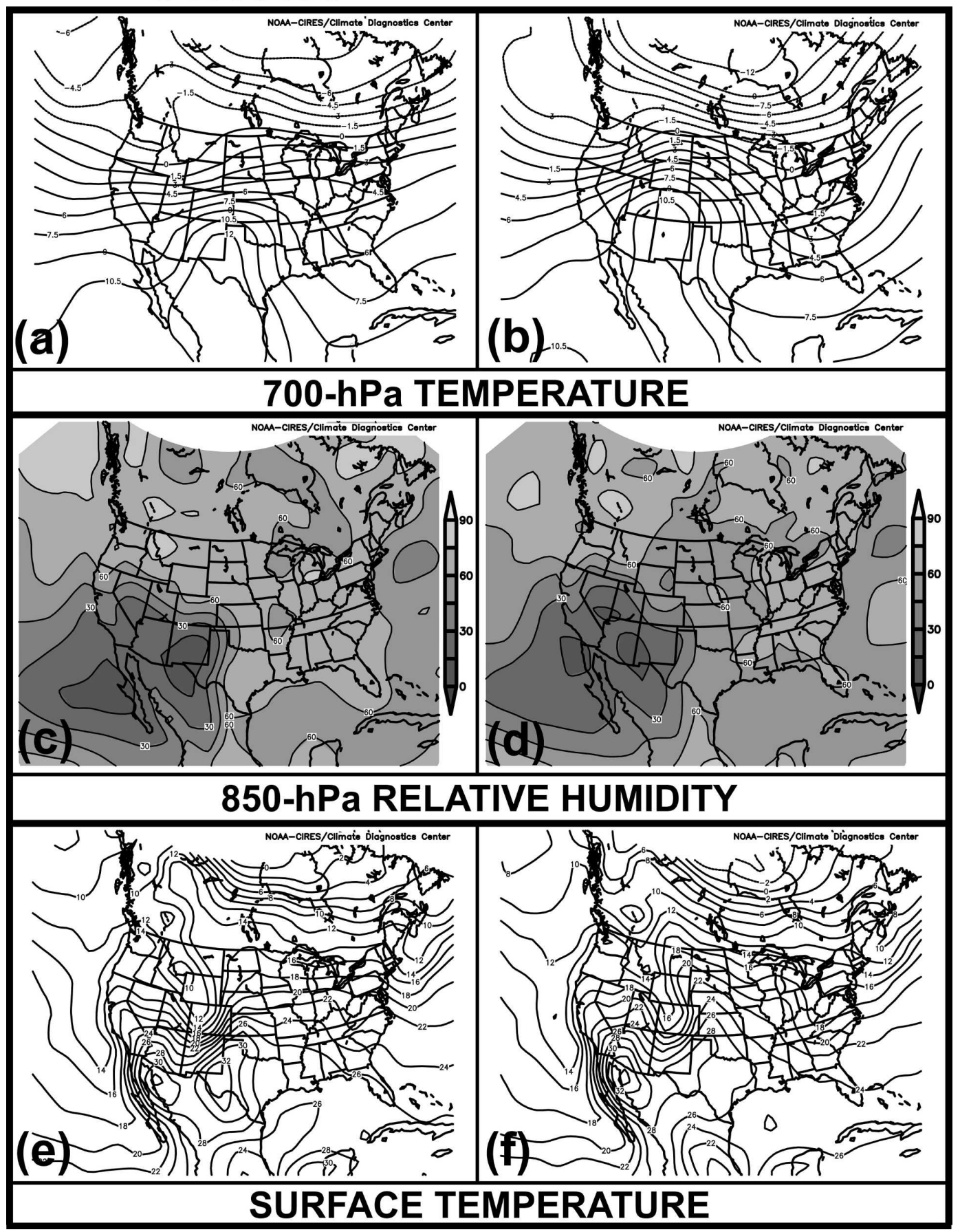

FIG. 5. (left) STRONG vs (right) WEAK dryline composites: (a) and (b) 700-hPa temperature [every $1.5^{\circ} \mathrm{C}$; positive and zero (negative) values solid (dashed)]; (c) and (d) 850-hPa relative humidity (shaded and contoured every $15 \%$ according to scale); (e) and (f) surface temperature [every $2^{\circ} \mathrm{C}$; positive and zero (negative) values solid (dashed)].

airstream in the conceptual model of extratropical cyclones; e.g., Carlson 1980) may also be contributing to the steep lapse rates of this midtropospheric nearly dry adiabatic layer, as noted by other investigators (e.g.,
McCarthy and Koch 1982; see Peterson 1983 for a review). In the STRONG composite, lapse rates are maximized at about $7.8^{\circ} \mathrm{C} \mathrm{km}^{-1}$ over west Texas (Fig. 6a), collocated with the high 700-hPa temperatures 
STRONG

WEAK

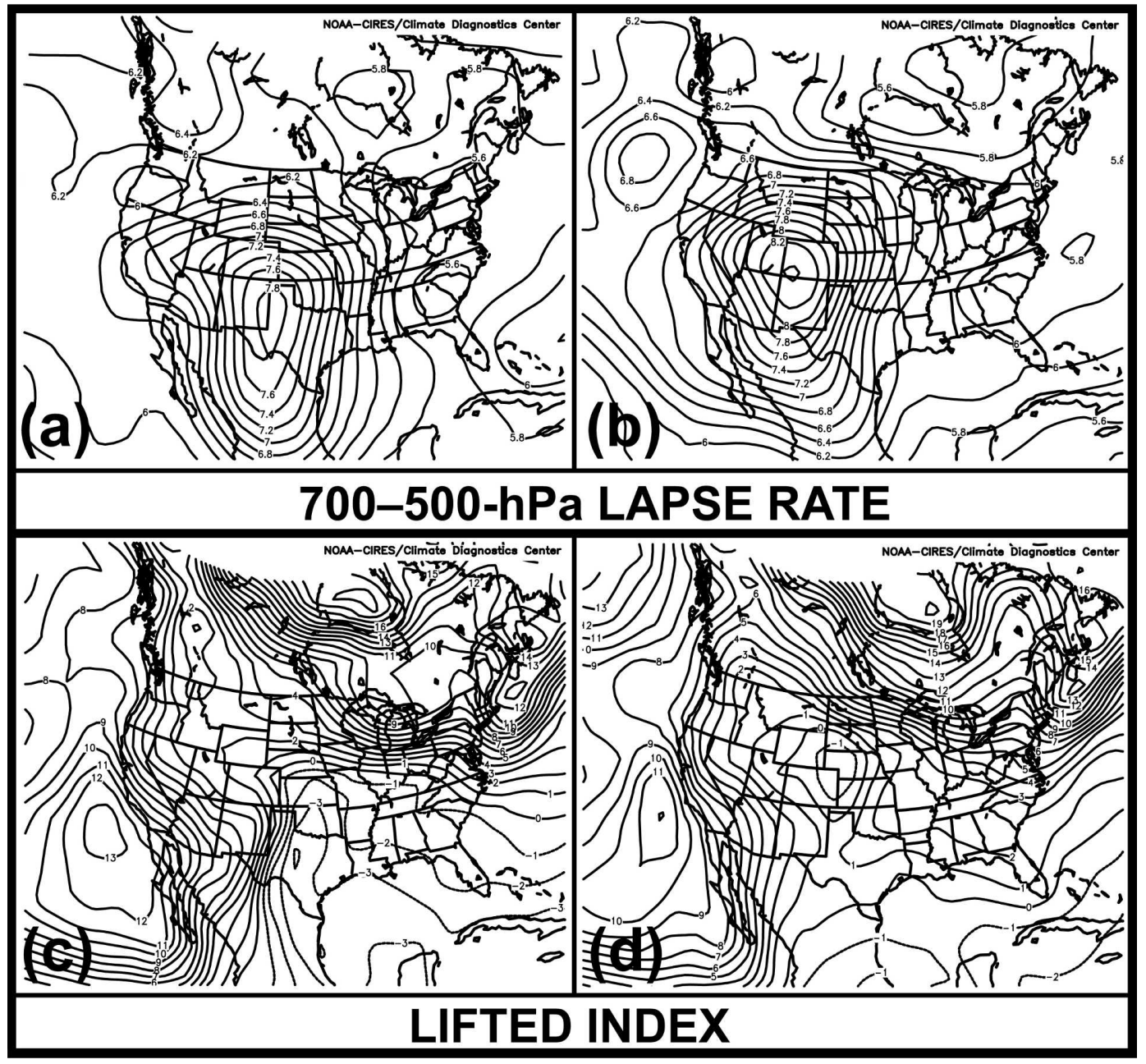

FIG. 6. (left) STRONG vs (right) WEAK dryline composites: (a) and (b) 700-500-hPa lapse rate (solid lines every $0.2^{\circ} \mathrm{C} \mathrm{km}^{-1}$ ); (c) and (d) surface-to-500-hPa lifted index [every $1^{\circ} \mathrm{C}$; positive and zero (negative) values solid (dashed)].

(Fig. 5a). In the WEAK composite, however, values exceed $8^{\circ} \mathrm{C} \mathrm{km}^{-1}$ (Fig. 6b), albeit shifted northwestward underneath the midtropospheric ridge over the southwestern United States (Fig. 3d) and high 700-hPa temperatures (Fig. 5b). The implication of the location of this low-stability air for the lifted index (Galway 1956) is dramatic. Lifted indices in the STRONG composite are less than $-4^{\circ} \mathrm{C}$ over central Texas east of the dryline but are positive over Texas in the WEAK composite (cf. Figs. 6c,d).

\section{Discussion}

The composite analyses provide insight into the importance of the synoptic-scale flow on the strength of the dryline. In particular, the convergence and deformation associated with the lower-tropospheric lee cyclone associated with the upper-level short-wave trough create an airstream boundary between the moist air from the Gulf of Mexico and the dry air to the west from the southwest United States. Previous research has indicated the importance of short-wave troughs to dryline intensification. Specifically, Rhea (1966) found $71 \%$ of his dryline cases occurred in association with a short-wave trough at $500 \mathrm{hPa}$. Such situations can be conducive to the movement of the dryline to the east. For example, Hoch and Markowski (2005) claimed that "virtually all" the drylines east of $97^{\circ} \mathrm{W}$ in their $30-\mathrm{yr}$ climatology were associated with eastward-moving cyclones. These results lend support to the distinction ad- 
vocated by Hane (2004) between synoptically active drylines (where upper-level synoptic forcing is important for the downward transport of the high momentum air west of the dryline) versus quiescent drylines (where such forcing is not present).

In the synoptically active dryline cases, the confluence of two airstreams afforded by the development of a lee trough sets the stage for a dryline to form. Contraction of the dewpoint gradient, likely enhanced by the frontogenetical circulations on the mesoscale and mixing processes on the microscale, then results to produce intense drylines. In synoptically quiescent drylines, synoptic-scale processes are not nearly as significant, and dryline intensification results primarily from frontogenesis and mixing. Indeed, the points on Fig. 2 in the lower-right quadrant of the figure (large dewpoint difference, but negative or small positive dryline confluence) are these types of events.

To illustrate the importance that synoptic-scale processes play in drylines of all strengths, a dataset of days with no surface airstream boundaries within the WTM was constructed. This dataset consisted of 59 dates (hereafter called NO BOUNDARY) where no dryline or front was inside or touching the domain of the WTM. Although some of these cases may feature an airstream boundary, these boundaries were well outside the WTM domain.

In the STRONG and WEAK composites (Figs. 3e,f), some semblance of a lee trough was usually in place for dryline development, even in the WEAK cases. In the NO BOUNDARY composite, however, the 500-hPa ridge to the west of west Texas (Fig. 7a) implied anticyclonic vorticity advection over west Texas and minimal lee troughing (Fig. 7b). Furthermore, the geostrophic southerlies, impressive even in the WEAK composite (Fig. 3f), are much weaker in the NO BOUNDARY composite (Fig. 7b). Without strong large-scale confluence from the lee troughing to bring the isodrosotherms together, the sharpening of the dewpoint gradient will take longer (possibly even longer than the daytime diurnal cycle), and the drylines may not be as strong. The results from Fig. 2 showing the strong correlation between $\Delta T_{d}$ and $\Delta u$ supports the principal role of synoptic-scale processes in starting this contraction process.

\section{Conclusions}

This study shows the importance of the synopticscale flow on regulating the strength of the dryline. Specifically, 64 days during the springs of 2004 and 2005 featuring a dryline were identified. The strength of the dryline was measured by the surface dewpoint tempera-

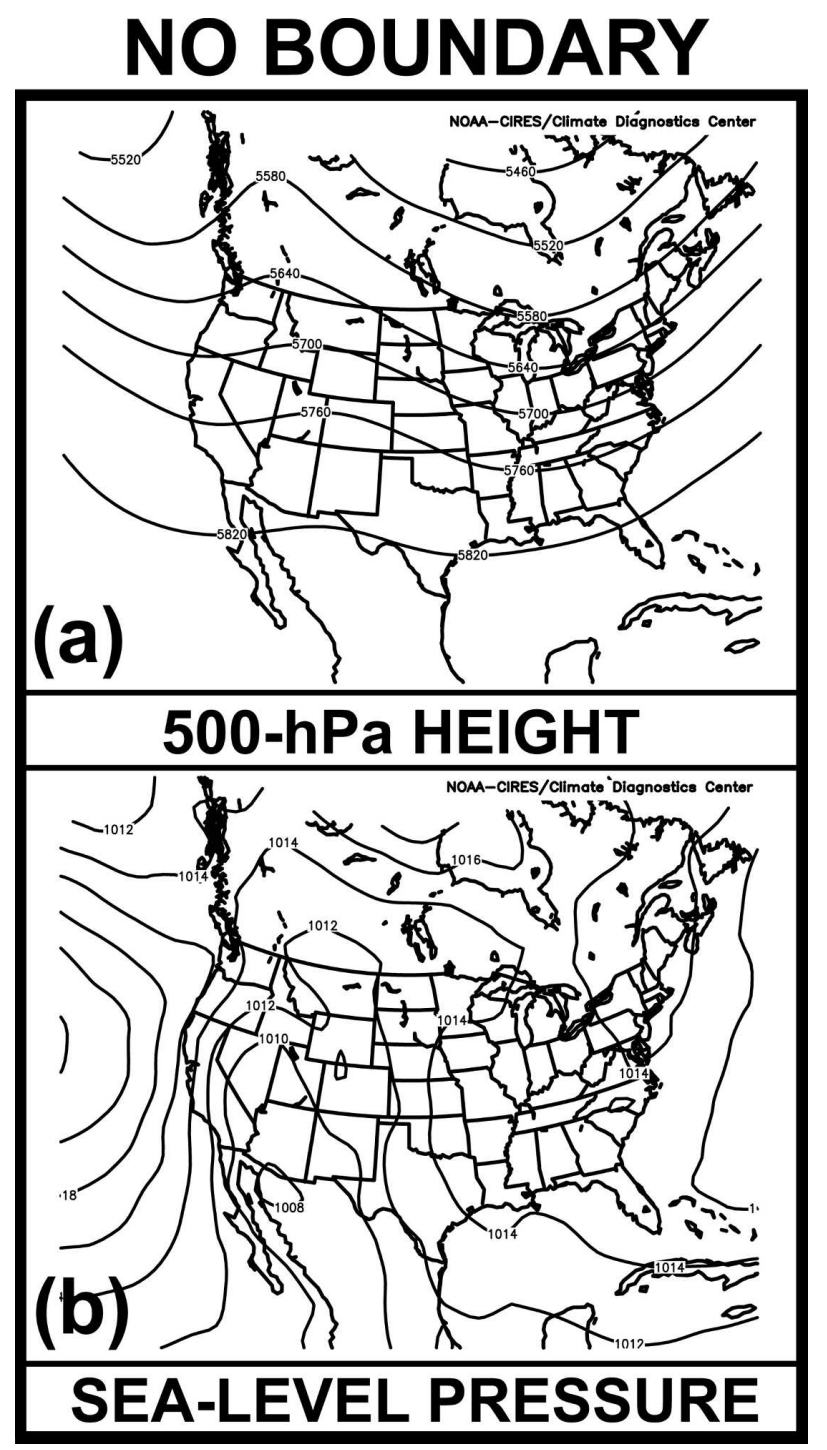

FIG. 7. NO BOUNDARY composite: (a) 500-hPa geopotential height (solid lines every $60 \mathrm{~m}$ ), and (b) sea level pressure (solid lines every $2 \mathrm{hPa}$ ).

ture difference between MORT and PADU $\left(\Delta T_{d}\right)$. Another variable from this dataset, $\Delta u$, represents the difference between MORT and PADU in the $u$ component of the wind, an expression we term the dryline confluence. A linear relationship exists between $\Delta T_{d}$ and $\Delta u$ with a Pearson correlation coefficient of 0.73 , indicating an important role for surface confluence in intensifying the dryline. Because this confluence is measured over the east-west dimension of the WTM domain $(230 \mathrm{~km})$, forcing on the synoptic scale is likely an important contributor in generating the most intense drylines. In events strongly influenced by the synoptic pattern (synoptically forced drylines), the confluence afforded by large-scale processes strongly supplements 
smaller-scale processes, such as frontogenesis and the vertical mixing of heat and momentum between the convective boundary layer and the free atmosphere, to produce the very intense moisture gradients observed across drylines (e.g., order of $1 \mathrm{~g} \mathrm{~kg}^{-1} \mathrm{~km}^{-1}$ in Atkins et al. 1998). In contrast, a few cases (the synoptically quiescent drylines) depart from this linear relationship. In these cases, the smaller-scale processes are primarily responsible for strengthening the dryline.

Composite synoptic analyses are constructed for the top and bottom quartiles of the 64 dryline days as measured by $\Delta T_{d}$, comprising 16 days each (termed STRONG and WEAK, respectively). The STRONG synoptic pattern is characterized by an upper-level short-wave trough approaching west Texas and an associated surface cyclone over eastern Colorado, northern Texas, and western Oklahoma. The strong dryline results from the confluence associated with the surface cyclone acting to intensify the ambient dewpoint gradient present in west Texas. In contrast, the WEAK synoptic pattern is characterized by an upper-level ridge over the central United States, weak lee troughing, and very weak surface cyclogenesis over the southwestern United States. Without a mechanism to externally supplement confluence over the region, the dryline remains weak. A third group termed NO BOUNDARY is composed of cases without a surface boundary within the WTM domain. The synoptic composite for NO BOUNDARY has no lee trough, with west Texas under implied anticyclonic vorticity advection aloft.

Few dryline studies in the previous literature present upper-level synoptic maps in association with the surface maps showing intense drylines. This omission shifts the focus from synoptic-scale processes favoring dryline intensification to the smaller-scale processes occurring at the drylines. Perhaps this small-scale focus is attributed to the nature of finescale field research that has taken place over the years along the dryline. The results of this study show the strong contribution of the synoptic-scale processes throughout the troposphere to regulating the strength of the dryline. Thus, we hope the results of this paper help to shift the focus back to a multiscale approach to understanding dryline strength. Remaining questions about the role of dryline strength in convection initiation and the production of severe weather will be addressed in a future manuscript.

Acknowledgments. This research began as a highschool research project between Schultz and Hoffman at Upper Arlington High School, Upper Arlington, Ohio; the assistance of Laura Brennan is greatly appreciated. Lance Bosart, Harold Brooks, Charles Doswell,
Carl Hane, Paul Markowski, Conrad Ziegler, and an anonymous reviewer provided helpful comments during the course of this research. Composite maps in Figs. 3-7 were provided by NOAA-CIRES Climate Diagnostics Center, Boulder, Colorado, from their Web site (http://www.cdc.noaa.gov). Cathy Smith (NOAA-CIRES Climate Diagnostics Center) added convective parameters to the Web page, allowing some composites to be performed. Funding for Schultz was provided by NOAA/ Office of Oceanic and Atmospheric Research under NOAA-University of Oklahoma Cooperative Agreement NA17RJ1227, U.S. Department of Commerce.

\section{REFERENCES}

Arnup, S. J., and M. J. Reeder, 2007: The diurnal and seasonal variation of the northern Australian dryline. Mon. Wea. Rev., in press.

Atkins, N. T., R. M. Wakimoto, and C. L. Ziegler, 1998: Observations of the finescale structure of a dryline during VORTEX 95. Mon. Wea. Rev., 126, 525-550.

Beebe, R. G., 1958: An instability line development as observed by the tornado research airplane. J. Meteor., 15, 278-282.

Carlson, T. N., 1980: Airflow through midlatitude cyclones and the comma cloud pattern. Mon. Wea. Rev., 108, 1498-1509.

— , S. G. Benjamin, G. S. Forbes, and Y.-F. Li, 1983: Elevated mixed layers in the regional severe storm environment: Conceptual model and case studies. Mon. Wea. Rev., 111, 14531473.

Cohen, R. A., and C. W. Kreitzberg, 1997: Airstream boundaries in numerical weather simulations. Mon. Wea. Rev., 125, 168183.

— , and D. M. Schultz, 2005: Contraction rate and its relationship to frontogenesis, the Lyapunov exponent, fluid trapping, and airstream boundaries. Mon. Wea. Rev., 133, 1353-1369.

Fujita, T., 1958: Structure and movement of a dry front. Bull. Amer. Meteor. Soc., 39, 574-582.

Galway, J. G., 1956: The lifted index as a predictor of latent instability. Bull. Amer. Meteor. Soc., 43, 528-529.

Geerts, B., R. Damiani, and S. Haimov, 2006: Finescale vertical structure of a cold front as revealed by an airborne Doppler radar. Mon. Wea. Rev., 134, 251-271.

Hane, C. E., 2004: Quiescent and synoptically-active drylines: A comparison based upon case studies. Meteor. Atmos. Phys., 86, 195-211.

— C. L. Ziegler, and H. B. Bluestein, 1993: Investigation of the dryline and convective storms initiated along the dryline: Field experiments during COPS-91. Bull. Amer. Meteor. Soc., 74, $2133-2145$.

- H. B. Bluestein, T. M. Crawford, M. E. Baldwin, and R. M. Rabin, 1997: Severe thunderstorm development in relation to along-dryline variability: A case study. Mon. Wea. Rev., 125, 231-251.

Hoch, J., and P. Markowski, 2005: A climatology of springtime dryline position in the U.S. Great Plains region. J. Climate, 18, 2132-2137.

Hoskins, B. J., and F. P. Bretherton, 1972: Atmospheric frontogenesis models: Mathematical formulation and solution. $J$. Atmos. Sci., 29, 11-37.

Jones, P. A., and P. R. Bannon, 2002: A mixed-layer model of the diurnal dryline. J. Atmos. Sci., 59, 2582-2593. 
Kalnay, E., and Coauthors, 1996: The NCEP/NCAR 40-Year Reanalysis Project. Bull. Amer. Meteor. Soc., 77, 437-471.

Keyser, D., and T. N. Carlson, 1984: Transverse ageostrophic circulations associated with elevated mixed layers. Mon. Wea. Rev., 112, 2465-2478.

McCarthy, J., and S. E. Koch, 1982: The evolution of an Oklahoma dryline. Part I: A meso- and subsynoptic-scale analysis. $J$. Atmos. Sci., 39, 225-236.

Miller, J. A., T. A. Kovacs, and P. R. Bannon, 2001: A shallowwater model of the diurnal dryline. J. Atmos. Sci., 58, 35083524.

Peckham, S. E., and L. J. Wicker, 2000: The influence of topography and lower-tropospheric winds on dryline morphology. Mon. Wea. Rev., 128, 2165-2189.

Peterson, R. E., 1983: The west Texas dryline: Occurrence and behavior. Preprints, 13th Conf. on Severe Local Storms, Tulsa, OK, Amer. Meteor. Soc., J9-J11.

Rhea, J. O., 1966: A study of thunderstorm formation along dry lines. J. Appl. Meteor., 5, 58-63.

Richter, H., and L. F. Bosart, 2002: The suppression of deep moist convection near the southern Great Plains dryline. Mon. Wea. Rev., 130, 1665-1691.

Roebber, P. J., D. M. Schultz, and R. Romero, 2002: Synoptic regulation of the 3 May 1999 tornado outbreak. Wea. Forecasting, 17, 399-429.

Schaefer, J. T., 1974a: The life cycle of the dryline. J. Appl. Meteor., 13, 444-449.

— 1974b: A simulative model of dryline motion. J. Atmos. Sci., 31, 956-964.

1986: The dryline. Mesoscale Meteorology and Forecasting, P. S. Ray, Ed., Amer. Meteor. Soc., 549-572.
Schroeder, J. L., W. S. Burgett, K. B. Haynie, I. Sonmez, G. D. Skwira, A. L. Doggett, and J. W. Lipe, 2005: The West Texas Mesonet: A technical overview. J. Atmos. Oceanic Technol., 22, 211-222.

Sun, W. Y., and Y. Ogura, 1979: Boundary layer forcing as a possible trigger to a squall line formation. J. Atmos. Sci., 36, 235-254.

- and C. C. Wu, 1992: Formation and diurnal variation of the dryline. J. Atmos. Sci., 49, 1606-1619.

Thompson, R. L., and R. Edwards, 2000: An overview of environmental conditions and forecast implications of the 3 May 1999 tornado outbreak. Wea. Forecasting, 15, 682-699.

Uccellini, L. W., 1980: On the role of upper tropospheric jet streaks and leeside cyclogenesis in the development of lowlevel jets in the Great Plains. Mon. Wea. Rev., 108, 1689-1696.

Weiss, C. C., and H. B. Bluestein, 2002: Airborne pseudo-dual Doppler analysis of a dryline-outflow boundary intersection. Mon. Wea. Rev., 130, 1207-1226.

$\longrightarrow,-$, and A. L. Pazmany, 2006: Finescale radar observations of the 22 May 2002 dryline during the International $\mathrm{H}_{2} \mathrm{O}$ Project (IHOP). Mon. Wea. Rev., 134, 273-293.

Ziegler, C. L., and C. E. Hane, 1993: An observational study of the dryline. Mon. Wea. Rev., 121, 1134-1151.

— , and E. N. Rasmussen, 1998: The initiation of moist convection at the dryline: Forecasting issues from a case study perspective. Wea. Forecasting, 13, 1106-1131.

—, W. J. Martin, R. A. Pielke, and R. L. Walko, 1995: A modeling study of the dryline. J. Atmos. Sci., 52, 263-285.

- T. J. Lee, and R. A. Pielke, 1997: Convective initiation at the dryline: A modeling study. Mon. Wea. Rev., 125, 1001-1026. 